\title{
Experiences within the Family of Origin and Intimate Partner Violence: A Dyadic Model Analysis
}

\author{
Josiane Razera ${ }^{1}$ \\ Lívia Maria Bedin ${ }^{2}$ \\ Eduarda Lima de Oliveira ${ }^{3}$ \\ Clarisse Pereira Mosmann ${ }^{3}$ \\ Denise Falcke ${ }^{3}$
}

\begin{abstract}
Intimate partner violence may be influenced by family experience. This study aims to test a dyadic model verifying the relationship between events experienced in the family of origin and intimate partner violence. This study addressed 304 heterosexual couples using a sociodemographic questionnaire, the Revised Conflict Tactics Scales (CTS2), and Family Background Questionnaire (FBQ). The analyses were performed using the actor-partner interdependence model (APIM) and the structural equation model. Less intense violence was positively and significantly correlated with violence perpetrated by husbands and wives $(r=0.661 ; p<0.01)$, whereas no correlation was found between severe violence and latent factors, excluding interdependence between the dyads. All the seven models presented satisfactory goodness of fit (CFI $>0.91$; RMSEA $<0.08)$, except for the dimension "sexual abuse". Therefore, the results reinforce that the events experienced in the family of origin influence intimate partner violence.
\end{abstract}

Keywords: family of origin, marital conflict, family violence

\section{Experiências na Família de Origem e Violência Conjugal: Análise do Modelo Diádico}

Resumo: A violência conjugal pode ser influenciada pela vivência familiar. Este estudo objetivou testar um modelo diádico de relação entre as experiências na família de origem e a violência conjugal. Realizou-se investigação com 304 casais heterossexuais com base em questionário de dados sociodemográficos, no Revised Conflict Tactics Scales (CTS2) e no Family Background Questionnaire (FBQ). As análises foram realizadas utilizando-se o modelo de interdependência ator-parceiro (APIM) por meio de equações estruturais. A violência de menor intensidade correlacionou-se positiva e significativamente entre a violência cometida pelos maridos e pelas esposas $(r=0,661 ; p<0,01)$. Já a violência grave não foi correlacionada significativamente entre os fatores latentes, excluindo a interdependência entre a díade. Entre os sete modelos testados, todos apresentaram bons índices de ajuste (CFI $>0,91$; RMSEA $<0,08)$, exceto a dimensão "abuso sexual”. Assim, reforça-se que as experiências vivenciadas na família estão relacionadas à violência conjugal.

Palavras-chave: família de origem, conflito conjugal, violência na família

\section{Experiencias Familiares de Origen y Violencia Conyugal: Análisis de un Modelo Diádico}

Resumen: La violencia conyugal puede verse influida por la experiencia familiar. Este estudio tiene como objetivo probar un modelo diádico de la relación entre las experiencias en la familia de origen y la violencia conyugal. Se llevó a cabo una investigación con 304 parejas heterosexuales, utilizando un cuestionario sociodemográficos, Revised Conflict Tactics Scales (CTS2) y Family Background Questionnaire (FBQ). Los análisis se realizaron utilizando el modelo de interdependencia actor-socio (APIM) utilizando ecuaciones estructurales. La violencia menos intensa se correlacionó positiva y significativamente entre la violencia cometida por maridos y esposas $(r=0,661$; $p<0,01)$, mientras que en la violencia severa no hubo correlación significativa entre los factores latentes, excluyendo interdependencia entre la díada. Entre los siete modelos probados, todos mostraron buenas tasas de ajuste (CFI $>0,91$; RMSEA $<0,08)$, excepto por la dimensión "abuso sexual”. Así, se refuerza que las experiencias vividas en la familia están relacionadas con la violencia conyugal.

Palabras clave: familia de origen, conflicto marital, violencia doméstica

${ }^{l}$ Faculdade Meridional de Passo Fundo, Passo Fundo-RS, Brazil ${ }^{2}$ Universidade Federal do Rio Grande do Sul, Porto Alegre-RS, Brazil

${ }^{3}$ Universidade do Vale do Rio dos Sinos, São Leopoldo-RS, Brazil This paper derived from the primary author's doctoral dissertation under the supervision of the last author, defended in 2018 to the Graduate Program in Clinical Psychology at the Universidade do Vale do Rio dos Sinos. CAPES/ PROSUP provided financial support.

Correspondence address: Josiane Razera. Universidade do Vale do Rio dos Sinos. Avenida Unisinos, São Leopoldo-RS, Brazil. CEP 93.022-000. E-mail: razera.josiane@gmail.com.br
Intimate partner violence has been more intensively studied since the $1970 \mathrm{~s}$ and has raised the attention of researchers in many countries (Hardesty \& Ogolsky, 2020). It is defined as physical, sexual and/or psychological abused perpetrated by at least one of the partners (Martins, Rato, \& Marques, 2018). Even though these forms of violence is commonly addressed by researchers, Straus, Hamby, Boney-McCoy and Sugarman (1996) consider physical injury to be different from physical assault, highlighting 
the consequences of violent acts, such as sprains, bruises, and fainting, for instance.

Intimate partner violence is usually associated with, and often explained by, gender issues and based on the social construction of unequal power between men and women (Brancaglioni \& Fonseca, 2016). Hence, this analysis still considers women to be fragile (Rodrigues, Machado, Santos, Santos, \& Diniz, 2016). Another perspective considers there is a relational bias in domestic violence. Bates, Graham-Kevan and Archer (2014) addressed 706 women and 398 men and did not find substantial differences in violent behavior when considering gender and the context in which aggression took place.

It does not mean that in specific violent contexts, victims and aggressors cannot be identified, considering that men and women interact in complex social, cultural, and familial contexts, demanding individualized assessments. Hence, the spouses' different experiences of violence, including their families of origin, tend to influence relationships established in adulthood, especially marital relationships (Brennan, Borgman, Watts, Wilson, \& Swartout, 2020; Madalena, Carvalho, \& Falcke, 2018). Repeated behaviors may be associated with the transgenerational concept, which is seen as a set of behavioral and relational models transmitted from a generation to another. These family models can influence new relationships individuals establish throughout life (Camicia, Silva, \& Schmidt, 2016).

Tondowski et al. (2014) verified that violencerelated family patterns are recurrent via intergenerational transmissions and manifest as physical or verbal aggression, in the form of crying or silence, throughout the different generations studied. The experiences within the family of origin that may affect the future relationships of children include: (a) physical violence perpetrated by the parents/ caregivers during childhood (Barros \& Freitas, 2015); (b) the parents' psychological maladjustment such as the presence of emotional problems (Bouvette-Turcot, Bernier, \& Leblanc, 2017); (c) parenting styles, especially physical neglect (De Antoni \& Batista, 2014); (d) parental alliance, which refers to the relationship between parents regarding the upbringing of children or even potential situations of violence between the couple (J. M. M. Silva, Lima, \& Ludermir, 2017).

Fehringer and Hindin (2009) investigated these relational and transgenerational patterns in the Philippines and highlighted the role of witnessing violence and intimate partner violence during childhood. Having witnessed physical violence between parents during childhood predicted intimate partner violence among 472 participants. In Brazil, 10 couples reported that the choice of a spouse went through the selection of individuals who consumed alcohol, which enabled that their family history would be repeated (Feijó et al., 2016). The use of alcohol, violence perpetrated by parents, helplessness, and loss of loved ones were common among the 10 mothers who used to assault their children (D.I. Silva, Maftum, \& Mazza, 2014).

Scientific evidence suggests that violence can perpetuate for generations within the same family. However, the literature lacks investigations considering dyadic interactions (De Andrade, Cassepp-Borges, Ferrer, \& Sanchez-Aragón, 2017), especially in the context of intimate partner violence (Razera, Gaspodini, \& Falcke, 2017). There are dynamics in which an interdependent relationship is established between couples so that dyadic analyses have the advantage of providing a deeper understanding of the phenomenon under study (De Andrade et al., 2017). Because this is a complex phenomenon, this study aimed to test a dyadic model of the relationship between the events experienced within the family of origin and intimate partner violence.

\section{Method}

A quantitative, descriptive and explanatory study was conducted. An explanatory study is intended to deepen knowledge concerning a given context and explains the occurrence of the phenomenon under study (Hernández Sampieri, Fernández Collado, \& Baptista Lucio, 2013).

\section{Participants}

A total of 304 heterosexual couples, 18+ years old, officially married or in a stable union for at least six months participate in this study. A convenience sample was recruited through snowball sampling (Biernacki \& Waldorf, 1981). The inclusion criteria were being $18+$ years old and having cohabited for at least six months.

Regarding their marital situation, 169 couples $(55.6 \%)$ were officially married, and $135(44.4 \%)$ were in a stable union. The women were aged 37.72 on average $(S D=12.55)$, and men were aged $40.01(S D=12.75)$. The duration of the relationships ranged from one to 56 years $(M=14.30$; $S D=11.09$ ). Table 1 presents other characteristics of the sample, not including missing data. 
Table 1

Sample's sociodemographic characteristics

\begin{tabular}{|c|c|c|c|c|c|}
\hline & \multirow{2}{*}{ Characteristics } & \multicolumn{2}{|c|}{ Men } & \multicolumn{2}{|c|}{ Women } \\
\hline & & $N$ & $\%$ & $N$ & $\%$ \\
\hline \multirow{2}{*}{$\begin{array}{l}\text { One of the spouses were previously } \\
\text { married }\end{array}$} & Yes & 66 & 21.7 & 49 & 16.1 \\
\hline & No & 236 & 77.6 & 253 & 83.2 \\
\hline \multirow[t]{2}{*}{ Children } & Yes & 202 & 66.4 & 201 & 66.1 \\
\hline & No & 101 & 33.2 & 103 & 33.9 \\
\hline \multirow[t]{6}{*}{ Education } & Illiterate & 4 & 1.3 & 2 & 0.7 \\
\hline & Primary/Middle school & 37 & 12.2 & 29 & 9.5 \\
\hline & High school & 115 & 37.8 & 76 & 25 \\
\hline & College studies & 82 & 27 & 117 & 38.5 \\
\hline & Bachelor's degree & 34 & 11.2 & 34 & 11.2 \\
\hline & Graduate studies & 25 & 8.2 & 43 & 14.1 \\
\hline \multirow[t]{2}{*}{ Paid job } & Yes & 266 & 87.5 & 245 & 80.6 \\
\hline & No & 37 & 12.2 & 54 & 17.8 \\
\hline
\end{tabular}

\section{Instruments}

Sociodemographic questionnaire. A form composed of 19 questions addressing the participants' characteristics and their relationships, such as gender and age, among others.

Revised conflict tactics scales (CTS2). This scale was developed by Straus et al. (1996) and adapted to Portuguese by Moraes, Hasselmann and Reichenheim (2002). It assesses violence in marital relationships and is composed of 78 questions addressing the actions of the respondents and their partners, distributed into five subscales: negotiation, psychological aggression, physical assault, injury, and sexual coercion, subdivided into minor and severe considering the intensity of acts.

The following subscales were used in this study: (1) Physical assault: minor - pushing, slapping, or twisting an arm; severe - punching, kicking, throwing against a wall, using a knife or firearm; (2) Psychological aggression: minor - insulting, swearing, or turning the back in the middle of a fight; severe - insults such as calling the person ugly, fat, or "bad in bed"; (3) Sexual coercion: minor - insistence in having sex, or oral or anal sex, without using physical force; Severe - same actions though using physical force or weapons to coerce the partner; (4) Injury: minor - bruises, purple spots, small cuts or pain; severe - requires medical assistance after a fight, fainting, or breaking bones.

The instrument is presented as a self-reported checklist (Moraes et al., 2002). The scale presented a Cronbach's alpha equal to 0.79 for perpetration and equal to 0.80 for victimization (Straus et al., 1996). Only data concerning the perpetration of violence were used in this study. The alpha for the women scale was 0.884 and for the men was 0.908 , which is considered very good (Hernández Sampieri et al., 2013).

Family background questionnaire (FBQ). Self-reported instrument developed by Melchert (1998). It comprises 179 statements rated on a Likert scale, distributed on 22 subscales concerning the participants' memories of events experienced in their families of origin.
A total of 61 items were assessed in this study concerning the following subscales: (1) Parental physical abuse (father/ mother) - physically violent behavior toward children; (2) Sexual abuse - any sexual act or game performed by parents, relatives, familiar or unfamiliar individuals. (3) Physical neglect - the parents do not provide physical care, for instance, food, hygiene, medical care, or clothing. (4) Substance abuse (father/mother) - parents' alcohol or drug abuse. (5) Psychological maladjustment (father/ mother) - the parents present mental disorders such as psychopathologies, mood changes, or abuse of substances; (6) Parental alliance - level of agreement between parents concerning rules and guidance provided to children and whether there is violence in the parents' relationship.

One Brazilian study (Falcke, Wagner, \& Mosmann, 2008) obtained reliability indexes equal to 0.99 , which according to Hernández Sampieri et al. (2013), are very good parameters. The alpha obtained in this study for the full scale directed to women was 0.789 and 0.773 for the scale directed to men.

\section{Procedure}

Data collection. Data were collected at the couples' homes or in places suggested by them. The authors simultaneously applied the instruments to the couple to ensure the independence of responses.

Data analysis. The analyses were based on the ActorPartner Interdependence Model - APIM (Kenny, Kashy, \& Cook, 2006), which considers the independence between individuals involved in dyadic relationships (couple); that is, each member of the pair directly or indirectly influence each other's emotions and behaviors as they share the same context and are exposed to similar influences (Cook \& Kenny, 2005; Kenny et al., 2006). The method of dyadic analysis of data was based on Structural Equation Modeling - SEM, a multivariate technique used to analyze data that enables to empirically and simultaneously test a theoretical model 
of multiple relations (Byrne, 2010), which is coherent to the complexity of psychological phenomena (Pilati \& Laros, 2007). The models were assessed based on goodness of fit indexes. In addition to Chi-square Batista, Foguet and Coenders Gallart (2000) recommends Comparative Fit Index de Bentler - CFI Root Mean Square Error of Approximation - RMSEA. The analyses were performed with IBM SPSS ${ }^{\circledR}$ Amos $^{\text {TM }} 19$.

\section{Ethical Considerations}

This study was approved by the Institutional Review Board at the Universidade do Vale do Rio dos Sinos (CAAE No. 09/117, Protocol 11/129) and is in agreement with ethical guidelines regulating studies addressing human subjects, according to Resolution 510/2016, National Council of Health. The couples' participation was conditioned to them signing free and informed consent forms, and the participants' identities remained confidential.

\section{Results}

Data were organized by gender in order to assess the heterosexual couples composing this study's sample. Note that the people in a dyad be ordered in an equivalent manner (Alferes \& Kenny, 2009). Each individual in a dyadic model is matched with another person, and the pairs are measured by the same set of variables. Hence, the first analysis of dyadic data seeks to establish the extension to which both answers are correlated, that is, whether there is interdependence (also known as nonindependence) between the results. Non-independence can be used to infer reciprocity or influence and requires that data are analyzed to include the individuals and dyad as units of analysis (Kenny et al., 2006).

\section{Measuring nonindependence}

The level of interdependence among the events experienced in the family of origin and intimate partner violence may occur due to factors associated with the fact these individuals are closely related and exposed to similar experiences (Cook \& Kenny, 2005; Kenny et al., 2006). Nonindependence is determined by an association between the scores obtained by the members of a dyad. For couples with distinguishable members, as in this study, nonindependence can be measured using the Person's coefficient (Kenny et al., 2006). The correlations between the CTS2 and FBQ variables are presented in Table 2.

Table 2 shows that most of the dimensions are significantly correlated between the dyad members, indicating that the constructs are interdependent between the spouses. The CTS2's variables "severe physical assault" "paternal physical abuse" and FBQ's "sexual abuse" were not significantly correlated, and for this reason, not included in the Actor-Partner Interdependence Model (APIM).
Table 2

Pearson's correlations between men and women for the CTS2 and FBQ variables

\begin{tabular}{lc}
\hline \multicolumn{1}{c}{ CTS and FBQ Variables } & Correlations \\
\hline Minor Psychological aggression & $.553^{* *}$ \\
Severe Psychological aggression & $.178^{* *}$ \\
Minor injury & $.424^{* *}$ \\
Severe injury & $.222^{* *}$ \\
Minor Physical Violence & $.373^{* *}$ \\
Severe Physical Violence & .074 \\
Minor Sexual Coercion & $.148^{*}$ \\
Severe Sexual Coercion & $.970^{* *}$ \\
Paternal physical abuse & .055 \\
Maternal physical abuse & $.132^{*}$ \\
Sexual Abuse & -.043 \\
Physical Neglect & $.320^{* *}$ \\
Paternal Substance Abuse & $.127^{*}$ \\
Maternal Substance Abuse & $.538^{* *}$ \\
Paternal Psychological Abuse & $.156^{* *}$ \\
Maternal Psychological Abuse & $.124^{*}$ \\
Parental Alliance & $.217^{* *}$ \\
\hline$* p<0.05 * * p<0.01$. &
\end{tabular}

\section{Confirmatory factor analysis with distinguishable dyads}

The Confirmatory Factor Analyses (CFA) enable verifying the correlations between the dyads' latent variables and see whether there is nonindependence. To verify the correlations between latent variables, one has to analyze the factorial invariance of each scale in both groups to see whether the constructs have the same meaning in each group. In this study, the difference between the CFI $(\triangle \mathrm{CFI})$ from one model to another should not be greater than 0.010 . Therefore, the results indicate the feasibility of restricting factor loads to be the same in different groups (Milfont \& Fischer, 2010). We tested the metric invariance of each scale with restricted and equalized factor loadings between the groups of the same structural model. The goodness of fit for the CFA for each scale is presented in Table 3.

The CTS-Minor and CTS-Severe final models, both the unrestricted model as the one with restricted factor loadings, presented satisfactory goodness of fit. Concerning minor violence perpetrated by men, the highest factor loading for "physical assault" was 0.890 , and the lowest was 0.257 for "sexual coercion". The highest factor loading for women was 0.627 for "physical assault" and the lowest was 0.327 for "sexual coercion". Regarding men's severe violence, the highest loading was 0.962 for "injury" and the lowest was 0.563 for "psychological aggression". Among women, the highest load for severe violence was 0.364 for "physical assault" and the lowest was 0.10 for "psychological aggression". 
The FBQ did not show satisfactory goodness of fit when the latent variables were included, even when applying suggested changes to the model. For this reason, the following analyses only included the dimensions observed, considering the sum of the items for each of the nine dimensions.

Once factor invariance was verified, the next step was determining the degree of correlation between the pair's CTS latent variables, which meets the assumption of nonindependence. Regarding the CTS-minor, a positive and significant correlation was found between the violence perpetrated by men and women $(r=0.661 ; p<0.01$, Figure 1$)$. The correlation between latent factors was not significant for the CTS-Severe, $(r=0.057 ; p=0.352)$, indicating no interdependence within the dyad. Therefore, APIM was performed with the CTS-Minor only.

Table 3

Dyadic Confirmatory Factor Analysis for CTS2 and FBQ - Goodness of fit

\begin{tabular}{lccccc}
\hline \multicolumn{1}{c}{ Model } & $\chi 2$ & $g l$ & $p$ & $C F I$ & $R M S E A$ \\
\hline CTS-Minor - unrestricted model & 35.71 & 14 & 0.001 & 0.961 & 0.072 \\
CTS- Minor - restricted factor loadings & 40.86 & 17 & 0.001 & 0.957 & 0.068 \\
CTS-Severe - unrestricted model & 4.60 & 3 & 0.203 & 0.998 & 0.042 \\
CTS-Severe - restricted factor loadings & 5.58 & 5 & 0.348 & 0.999 & 0.020 \\
FBQ - unrestricted model & 555.44 & 129 & 0.01 & 0.714 & 0.104 \\
\hline
\end{tabular}

\section{Actor-partner interdependence model (APIM)}

When using the Structural Equation Modeling (SEM), APIM enables simultaneously verifying the effects of individuals and partners on the study's dependent variable. Figure 1 presents APIM with the variables of violence-related experiences within the family of origin of men and women. There are two actor effects in this model, understood here as the effect of events the individual who perpetrates violence experienced in his/her family of origin: the first "female actor effect" is measured by the relationship between the events a woman experienced in her family of origin and the violence she perpetrates. The second "male actor effect" is measured by the relationship between the events a man experienced in his family of origin and the violence he perpetrates.

Additionally, partner effects in the model suggest that an actor's experiences from his/her family of origin are related to the violence perpetrated by his/her partner. The first "female partner effect" is measured by the relationship between the events a woman experienced in her family of origin and the violence her partner perpetrates. The second "male partner effect" is measured by the relationship between the experiences of a man with his family of origin and the violence his partner perpetrates.

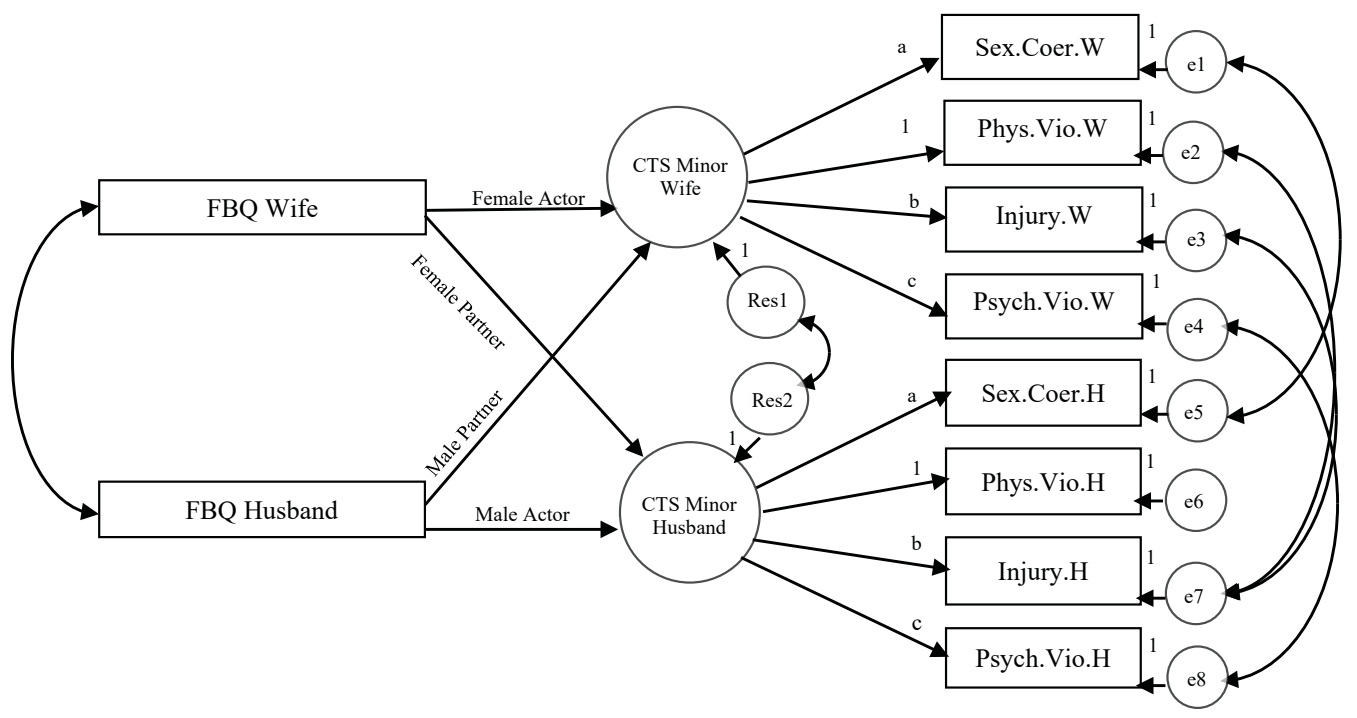

Figure 1. APIM - Relationship between the individuals' FBQ and CTS-Minor.

Seven models were estimated - one for each of the FBQ's dimensions ("paternal physical abuse" and "sexual abuse" were not tested because they did not meet the interdependence assumption between the dyad - see Table 2). All the models presented satisfactory goodness of fit, considering the model with the restricted factor loadings to be equal between groups $(\mathrm{CFI}>0.91 ;$ RMSEA $<0.08$, RMSEA $<0,001)$. Table 4 presents the parameters of the APIM for the CTSMinor, considering the actor and partner effects for each of the FBQ's seven dimensions. The parameters represent the effect of regressions on the actor-partner interdependence models, analyzed with structural equations. 
Table 4

APIM's parameters concerning the relationship between the $F B Q$ dimensions and the CTS-Minor latent variable

\begin{tabular}{|c|c|}
\hline & $\begin{array}{l}\text { CTS-Minor } \\
\text { Parameters }\end{array}$ \\
\hline \multicolumn{2}{|l|}{ FBQ Physical neglect } \\
\hline Female actor effect & -0.133 \\
\hline Male actor effect & $0.183^{* *}$ \\
\hline Female partner effect & 0.004 \\
\hline Male partner effect & 0.007 \\
\hline \multicolumn{2}{|c|}{ FBQ Maternal physical abuse } \\
\hline Female actor effect & $0.188 * *$ \\
\hline Male actor effect & $0.181 * *$ \\
\hline Female partner effect & 0.079 \\
\hline Male partner effect & 0.040 \\
\hline \multicolumn{2}{|c|}{ FBQ Paternal substance abuse } \\
\hline Female actor effect & 0.022 \\
\hline Male actor effect & 0.013 \\
\hline Female partner effect & 0.073 \\
\hline Male partner effect & -0.069 \\
\hline \multicolumn{2}{|c|}{ FBQ Maternal substance abuse } \\
\hline Female actor effect & $0.183^{*}$ \\
\hline Male actor effect & 0.055 \\
\hline Female partner effect & -0.022 \\
\hline Male partner effect & -0.117 \\
\hline \multicolumn{2}{|c|}{ FBQ Paternal psychological maladjustment } \\
\hline Female actor effect & $0.285^{* *}$ \\
\hline Male actor effect & 0.104 \\
\hline Female partner effect & 0.111 \\
\hline Male partner effect & $0.138^{*}$ \\
\hline \multicolumn{2}{|c|}{ FBQ Maternal psychological maladjustment } \\
\hline Female actor effect & $0.295^{* *}$ \\
\hline Male actor effect & $0.223 * *$ \\
\hline Female partner effect & $0.125^{*}$ \\
\hline Male partner effect & 0.080 \\
\hline \multicolumn{2}{|l|}{ FBQ Parental Alliance } \\
\hline Female actor effect & $0.305^{* *}$ \\
\hline Male actor effect & 0.065 \\
\hline Female partner effect & $0.157 *$ \\
\hline Male partner effect & 0.074 \\
\hline
\end{tabular}

$* p<0.05 ; * * p<0.01$

The results indicate that physical neglect experienced by a man in his family of origin was associated with violence he perpetrates. Maternal physical abuse influenced the violence perpetrated by men and women. Paternal substance abuse did not present significant associations; however, maternal substance abuse witnessed by a woman was related to the violence she perpetrates within the relationship. Paternal psychological maladjustment was significantly associated with violence perpetrated by women and the victimization of men. Maternal psychological maladjustment was associated with violence perpetrated and experienced by women, and violence perpetrated by men. Finally, parental alliance was significantly associated, though with a small magnitude, with violence women perpetrate and experience; other variables may reflect on the violence phenomenon.

\section{Discussion}

These results reinforce the power of events experienced in one's family of origin to predict behavioral models that repeat in adult relationships (Madalena et al., 2018). For male actors, some experiences from the family of origin influence the violence they perpetrate, such as neglect, maternal physical abuse, and maternal psychological maladjustment. Regarding physical neglect, it is known that its occurrence may trigger feelings of inability, worthlessness, and vulnerability (De Antoni \& Batista, 2014).

Maternal physical abuse experienced during childhood was associated with violence perpetrated by men, which is in line with Moura et al. (2020), showing that men who reported physical abuse during childhood were more likely to perpetrate violence in a marital relationship. From the same perspective, Vieira, Perdona, and Santos (2011) showed that women whose spouses were abused during childhood were three times more likely to be victimized.

Another experience from the family of origin that had an effect on male actors was maternal psychological maladjustment, which is when the mother presents psychological disorders. Thus, the parents' mental problems affect children and families (Bouvette-Turcot et al., 2017); the assumption is that parents/adults are supposed to meet the children's basic needs (i.e., physical, behavioral, and emotional needs) to ensure they develop healthy (Schavarem \& Toni, 2019); otherwise, children may grow into adults with dysfunctional behavior and emotions. These results indicate that violent behavior may perpetuate in marital relationships.

When assessing the men's experiences in their families of origin, the male partner effect influenced the violence perpetrated by their spouses; that is, the male partner effect was associated with the paternal psychological maladjustment dimension. This finding is in line with Hou, Yu, Fang and Epstein (2016) that violence perpetrated by a man's parents makes this man more likely to be victimized by his spouse. However, these findings differ in terms of the parent's and child's genders. In this study, the men who experienced paternal psychological maladjustment were more likely to be victimized by their spouses. In the study above, when the aggressor was a man, they also perpetrated violence, as if they identified themselves with the aggressor.

Regarding the female actor effect, the women's experiences from their families of origin that influence the violence they perpetrate included: maternal physical abuse, maternal substance abuse, paternal and maternal psychological maladjustment, and parental alliance. These findings corroborate the notion that violence perpetrated by the mothers is probably the one with the most potent effect 
(Hou et al., 2016) and that there is an association between the parent's genders with the aggressor's gender. Maternal physical abuse and maternal psychological maladjustment were associated with female aggressors, corroborating the findings reported by a previous study (Kerley, Xu, Sirisunyaluck, \& Alley, 2010).

Scientific studies indicate that the mother (Pinto Junior, Cassepp-Borges, \& Santos, 2015) is the primary kinship figure responsible for physical violence perpetrated against children. The hypothesis possibly explaining it is that mothers are the parental figure most frequently present (Nunes \& Sales, 2016) and more frequently involved with domestic activities. There is a potential association between having experienced or experience intimate partner violence and a woman's violent parental conditions, increasing the likelihood they will also show violent upbringing practices (J.M.M. Silva et al., 2017). This finding is in line with the parental alliance variable, which influences the violence perpetrated by women. Parental alliance refers to the relationship between parents regarding how to raise their children and even the existence of a violent relationship between the couple. Carneiro et al. (2017) consider that the violence experienced by women compromises their physical and mental health and that of their children. Children who witness violence are more likely to experience violence in their future relationships.

Maternal substance use was associated with female actors. There may be a pattern in which female aggressors repeat substance abuse, which needs to be further investigated. One study (Cezario, Carvalho, \& Lourenço, 2016) reveals that most of the men victimized by their spouses reported the presence of alcohol and drugs. When the female partner effect was assessed, the women's experiences from her family of origin that influenced the violence perpetrated by their spouses included maternal psychological maladjustment and parental alliance. Having a mother with mental problems and witnessing violence or disagreement in one's parents' marital relationship seems to compromise the daughters' future relationships. That is, they will likely seek partners that make them relive those experiences, with a potential association with reference figures (Tondowski et al., 2014).

These results show that men and women perpetrated violence and/or were victimized under the influence of different family experiences, ratifying the notion that these behaviors, even when re-signified, may repeat for generations, corroborating the transgenerational perspective of violence. Violence is a complex phenomenon; however, the results reveal that men and women are victimized or perpetrate violence in their marital relationships and the events experienced in their families of origin influence both the violence they experience and perpetrate.

Future studies can address different marital configurations, including same-sex couples so that the gender variable can be further explored in situations of intimate partner violence. One of this study's limitations refers to collecting data using a convenient sample recruited from the general population; that is, this sample presented a low frequency of sexual abuse, which may explain why this variable did not present interdependence. Additionally, this study's cross-sectional design does not allow establishing causal relationships between the variables. Longitudinal studies including clinical populations are suggested.

\section{References}

Alferes, V. R., \& Kenny, D. A. (2009). SPSS programs for the measurement of nonindependence in standard dyadic designs. Behavior Research Methods, 41(1), 47-54. doi:10.3758/BRM.41.1.47

Barros, A. S., \& Freitas, M. F. Q. (2015). Violência doméstica contra crianças e adolescentes: Consequências e estratégias de prevenção com pais agressores [Domestic violence against children and adolescents: Consequences and prevention strategies with aggressive parents]. Pensando Famílias, 19(2), 102-114. Retrieved from http://pepsic.bvsalud.org/scielo.php?pid=S1679494X2015000200009\&script=sci_abstract\&tlng=en

Bates, E. A., Graham-Kevan, N., \& Archer, J. (2014). Testing predictions from the male control theory of men's partner violence. Aggressive Behavior, 40(1), 42-55. doi:10.1002/ab.21499

Batista Foguet, J., \& Coenders Gallart, G. (2000). Modelos de ecuaciones estructurales: Modelos para el análisis de relaciones causales [Models of structural equations: Models for the analysis of causal relationships]. Madrid, España: La Muralla.

Biernacki, P., \& Waldorf, D. (1981). Snowball sampling: Problems and techniques of chain referral sampling. Sociological Methods \& Research, 10(2), 141-163. doi:10.1177/004912418101000205

Bouvette-Turcot, A. A., Bernier, A., \& Leblanc, E. (2017). Maternal psychosocial maladjustment and child internalizing symptoms: Investigating the modulating role of maternal sensitivity. Journal of Abnormal Child Psychology, 45(1), 157-170. doi:10.1007/ s10802-016-0154-8

Brancaglioni, B. C. A., \& Fonseca, R. M. G. S. (2016). Intimate partner violence in adolescence: An analysis of gender and generation. Revista Brasileira de Enfermagem, 69(5), 946-955. doi:10.1590/0034-7167-2016-0408

Brennan, C. L., Borgman, R. A., Watts, S. S., Wilson, R. A., \& Swartout, K. M. (2020). Childhood neglect history, depressive symptoms, and intimate partner violence perpetration by college students. Journal of Interpersonal Violence. Advance online publication. doi:10.1177/0886260519900307

Byrne, B. M. (2010). Structural equation modeling with AMOS: Basic concepts, applications, and programming (2nd ed.) New York, NY: Routledge. 
Camicia, E. G., Silva, S. B., \& Schmidt, B. (2016). Abordagem da transgeracionalidade na terapia sistêmica individual: Um estudo de caso clínico. Pensando Famílias, 20(1), 68-82. Retrieved from http://pepsic.bvsalud.org/scielo. php?script=sci_arttext\&pid=S1679-494X2016000100006

Carneiro, J. B., Gomes, N. P., Estrela, F. M., Santana, J. D., Mota, R. S., \& Erdmann, A. L. (2017). Domestic violence: Repercussions for women and children. Escola Anna Nery, 21(4), e20160346. doi:10.1590/2177-9465-EAN-2016-0346

Cezario, A. C. F., Carvalho, L. L., \& Lourenço, L. M. (2016). Violência contra o homem perpetrada por sua parceira: Perspectivas de psicólogos e assistentes sociais [Violence against man perpetrated by his partner: Perspectives of psychologists and social workers]. Psicologia em Pesquisa, 10(1), 76-84. doi:10.24879/201600100010049

Cook, W. L., \& Kenny, D. A. (2005). The actor-partner interdependence model: A model of bidirectional effects in developmental studies. International Journal of Behavioral Development, 29(2), 101-109. doi:10.1080/01650250444000405

De Andrade, A. L., Cassepp-Borges, V., Ferrer, E., \& Sanchez-Aragón, R. (2017). Análises de dados diádicos: Um exemplo a partir da pesquisa com casais [Dyadic data analysis: An example from couples research]. Trends in Psychology, 25(4), 1571-1588. doi:10.9788/tp2017.4-05

De Antoni, C., \& Batista, F. A. (2014). Violência familiar: Análise de fatores de risco e proteção [Family violence: An analysis of risk factors and protection]. Diaphora, 3(2), 26-35. Retrieved from http://www.sprgs.org.br/diaphora/ ojs/index.php/diaphora/article/view/62

Falcke,D.,Wagner,A.,\&Mosmann,C.P.(2008).Therelationship between family-of-origin and marital adjustment for couples in Brazil. Journal of Family Psychotherapy, 19(2), 170-186. doi:10.1080/08975350801905020

Fehringer, J. A., \& Hindin, M. J. (2009). Like parent, like child: Intergenerational transmission of partner violence in Cebu, the Philippines. Journal of Adolescent Health, 44(4), 363-371. doi:10.1016/j.jadohealth.2008.08.012

Feijó, M. R., Noto, A. R., Silva, E. A., Locatelli, D. P., Camargo, M. L., \& Gebara, C. F. P. (2016). Álcool e violência nas relações conjugais: Um estudo qualitativo com casais [Alcohol and violence in marital relations: A qualitative study with couples]. Psicologia em Estudo, 21(4), 581-592. doi:10.4025/psicolestud.v21i4.31556

Hardesty, J. L., \& Ogolsky, B. G. (2020). A socioecological perspective on intimate partner violence research: A decade in review. Journal of Marriage and Family, 82(1), 454-477. doi:10.1111/jomf.12652

Hernández Sampieri, E., Fernández Collado, C., \& Baptista Lucio, M. P. (2013). Metodologia de pesquisa [Research methodology] (D. V. Moraes, Trans., 5th ed.). Porto Alegre, RS: Penso.
Hou, J., Yu, L., Fang, X., \& Epstein, N. B. (2016). The intergenerational transmission of domestic violence: The role that gender plays in attribution and consequent intimate partner violence. Journal of Family Studies, 22(2), 121-139. doi:10.1080/1322940 0.2015 .1045923

Kenny, D. A., Kashy, D. A., \& Cook, W. L. (2006). Dyadic data analysis. New York, NY: Guilford.

Kerley, K. R., Xu, X., Sirisunyaluck, B., \& Alley, J. M. (2010). Exposure to family violence in childhood and intimate partner perpetration or victimization in adulthood: Exploring intergenerational transmission in urban Thailand. Journal of Family Violence, 25(3), 337-347. doi:10.1007/s10896-009-9295-7

Madalena, M., Carvalho, L. F., \& Falcke, D. (2018). Intimate partner violence: The predictive power of experiences in the family of origin and of personality disorder traits. Trends in Psychology, 26(1), 75-91. doi:10.9788/tp2018.1-04pt

Martins, E., Rato, M., \& Marques, E. (2018). Violência familiar: Conceitos, impacto e intervenção dos profissionais de saúde [Family violence: Concepts, impact and intervention of health professionals]. Egitania Sciencia, 11(21), 7-22. Retrieved from http://www.egitaniasciencia.ipg.pt/files/egitania_ sciencia_21.pdf

Melchert, C. F. (1998). Wise teaching: Biblical wisdom and educational ministry. Norcross, GA: Trinity.

Milfont, T. L., \& Fischer, R. (2010). Testing measurement invariance across groups: Applications in cross-cultural research. International Journal of Psychological Research, 3(1), 111-130. doi:10.21500/20112084.857

Moraes, C. L., Hasselmann, M. H., \& Reichenheim, M. E. (2002). Adaptação transcultural para o português do instrumento" Revised Conflict Tactics Scales (CTS2)" utilizado para identificar violência entre casais [Portuguese-language cross-cultural adaptation of the Revised Conflict Tactics Scales (CTS2), an instrument used to identify violence in couples]. Cadernos de Saúde Pública, 18(1), 163-176. doi:10.1590/S0102311X2002000100017

Moura, J. Q., Bordini, T. C. P. M., Ennes, J. V., Kucera, M. F., Krindges, C., \& Habigzang, L. F. (2020). Homens autores de violência contra mulher: Um estudo descritivo [Men authors of violence against women: A descriptive study]. Contextos Clínicos, 13(1), 174197. doi:10.4013/ctc.2020.131.09

Nunes, A. J., \& Sales, M. C. V. (2016). Violence against children in Brazilian scenery. Ciência \& Saúde Coletiva, 21(3), 871-880. doi:10.1590/1413812320152 13.08182014 
Pilati, R., \& Laros, J. A. (2007). Modelos de equações estruturais em psicologia: Conceitos e aplicações [Structural equation modeling in psychology: Concepts and applications]. Psicologia: Teoria e Pesquisa, 23(2), 205-216. doi:10.1590/S0102-37722007000200011

Pinto Junior, A. A., Cassepp-Borges, V., \& Santos, J. G. (2015). Caracterização da violência doméstica contra crianças e adolescentes e as estratégias interventivas em um município do Estado do Rio de Janeiro, Brasil [Characterization of child abuse and intervention strategies in a city of Rio de Janeiro state, Brazil]. Cadernos Saúde Coletiva, 23(2), 124-131. doi:10.1590/1414-462X201500020062

Razera, J., Gaspodini, I. B., \& Falcke, D. (2017). Intimate partner violence and gender a/symmetry: An integrative literature review. Psico-USF, 22(3), 401-412. doi:10.1590/1413-82712017220302

Rodrigues, V. P., Machado, J. C., Santos, W. S., Santos, M. F. S., \& Diniz, N. M. F. (2016). Gender violence: Social representations of relatives. Texto \& Contexto - Enfermagem, 25(4), e2770015. doi:10.1590/0104-07072016002770015

Schavarem, L. N., \& Toni, C. G. S. (2019). A relação entre as práticas educativas parentais e a autoestima da criança [The relationship between parenting style and children's self-esteem]. Pensando Famílias, 23(2), 147-161. Retrieved from http://pepsic.bvsalud.org/scielo.php? script $=$ sci_arttext\&pid=S1679-494X2019000200012\& $\operatorname{lng}=\mathrm{pt} \&$ tlng $=\mathrm{pt}$

Silva, D. I., Maftum, M. A., \& Mazza, V. A. (2014). Vulnerability in child development: Influence of weak family bonds, substance abuse and domestic violence. Texto \& Contexto - Enfermagem, 23(4), 1087-1094. doi:10.1590/0104-07072014001700013

Silva, J. M. M., Lima, M. C., \& Ludermir, A. B. (2017). Intimate partner violence and maternal educational practice. Revista de Saúde Pública, 51, 34. doi:10.1590/ S1518-8787.2017051006848

Straus, M. A., Hamby, S. L., Boney-McCoy, S., \& Sugarman, D. B. (1996). The revised Conflict Tactics Scales (CTS2): Development and preliminary psychometric data. Journal of Family Issues, 17(3), 283-316. doi:10.1177/019251396017003001

Tondowski, C. S., Feijó, M. R., Silva, E. A., Gebara, C. F. P., Sanchez, Z. M., \& Noto, A. R. (2014). Intergenerational patterns of family violence related to alcohol abuse: A genogram-based study. Psicologia: Reflexão e Crítica, 27(4), 806-814. doi:10.1590/1678-7153.201427421

Vieira, E. M., Perdona, G. S. C., \& Santos, M. A. (2011). Factors associated with intimate partner physical violence among health service users. Revista de Saúde Pública, 45(4), 730-737. doi:10.1590/S0034-89102011005000034
Josiane Razera is a Professor at the Faculdade Meridional de Passo Fundo, Passo Fundo-RS, Brazil.

Livia Maria Bedin is a Professor at the Universidade Federal do Rio Grande do Sul, Porto Alegre-RS, Brazil.

Eduarda Lima de Oliveira Master student at the Universidade do Vale do Rio dos Sinos, São Leopoldo-RS, Brazil.

Clarisse Pereira Mosmann is a Professor at the Universidade do Vale do Rio dos Sinos, São Leopoldo-RS, Brazil.

Denise Falcke is a Professor at the Universidade do Vale do Rio dos Sinos, São Leopoldo-RS, Brazil.

\section{Authors' Contribution:}

All authors made substantial contributions to this study's conception and design, data analysis and interpretation, and reviewed and approved the manuscript final version. All the authors assume public responsibility for the manuscript's content.

\section{Associate Editor:}

Luciana Mourão Cerqueira e Silva

Received: Apr. 23, 2020

1st Revision: Sep. 06, 2020

2nd Revision: Nov. 20, 2020

Approved: Dec. 10, 2020

How to cite this article:

Razera, J., Bedin, L. M., Oliveira, E. L., Mosmann, C. P., \& Falcke, D. (2021). Experiences within the family of origin and intimate partner violence: A dyadic model analysis. Paidéia (Ribeirão Preto), 31, e3122. doi:https://doi.org/10.1590/1982-4327e3122 